\title{
Seasonal Time Measurement During Reproduction
}

\author{
Keisuke IKEGAMI ${ }^{1)}$ and Takashi YOSHIMURA ${ }^{1-3)}$ \\ 1)Laboratory of Animal Physiology, Graduate School of Bioagricultural Sciences, Nagoya University, Nagoya 464-8601, \\ Japan \\ 2) Avian Bioscience Research Center, Graduate School of Bioagricultural Sciences, Nagoya University, Nagoya 464-8601, \\ Japan \\ 3) Institute of Transformative Bio-molecules (WPI-ITbM), Nagoya University, Nagoya 464-8601, Japan
}

\begin{abstract}
Most species living outside the tropical zone undergo physiological adaptations to seasonal environmental changes and changing day length (photoperiod); this phenomenon is called photoperiodism. It is well known that the circadian clock is involved in the regulation of photoperiodism such as seasonal reproduction, but the mechanism underlying circadian clock regulation of photoperiodism remains unclear. Recent molecular analysis have revealed that, in mammals and birds, the pars tuberalis (PT) of the pituitary gland acts as the relay point from light receptors, which receive information about the photoperiod, to the endocrine responses. Long-day (LD)-induced thyroid-stimulating hormone (TSH) in the PT acts as a master regulator of seasonal reproduction in the ependymal cells (ECs) within the mediobasal hypothalamus (MBH) and activates thyroid hormone (TH) by inducing the expression of type 2 deiodinase in both LD and short-day (SD) breeding animals. Furthermore, the circadian clock has been found to be localized in the PT and ECs as well as in the circadian pacemaker(s). This review purposes to summarize the current knowledge concerning the involvement of the neuroendocrine system and circadian clock in seasonal reproduction.
\end{abstract}

Key words: Melatonin, Pars tuberalis, Photoperiodic time measurement, Thyroid hormone, Thyroid-stimulating hormone

(J. Reprod. Dev. 59: 327-333, 2013)

S asonal transitions between annual cycle stages force organisms iving outside the tropical zone to adapt their physiology and behavior to the environmental changes that occur. Such adaptations include reproduction, migration, hibernation, molting, antler growth, rutting, courting, nesting, and parental behavior. The mechanism responsible for timing such transitions by using environmental cues is critical to understanding how animals adapt to environmental variations. Seasonal breeders adapt their reproductive cycles to specific seasons in order to maximize offspring survival. Hamsters and many birds, which have a gestation period of several weeks and breed during the spring, are called long-day (LD) breeders. Goats, sheep and deer, which have a gestation period of approximately 6 months, breed during the autumn and are called short-day (SD) breeders. For both types of breeders, the offspring are born during spring and summer, when food is abundant. These seasonal breeders use the predictable annual cycle of day length (photoperiod) as a calendar; this phenomenon is called photoperiodism $[1,2]$. While photoperiod, temperature, and precipitation all show annual changes, photoperiodic changes are the most reliable seasonal environmental cue because of the stable annual cycle.

Seasonal reproduction is controlled by the hypothalamic-pituitarygonadal (HPG) axis. Gonadotropin-releasing hormone (GnRH) synthesized mainly in the preoptic area (POA) of the hypothalamus is secreted from the median eminence (ME) into the hypophyseal portal vessels. Secreted GnRH activates the secretion of gonadotropins

Received: March 31, 2013

Accepted: April 7, 2013

(C2013 by the Society for Reproduction and Development

Correspondence: T Yoshimura (e-mail: takashiy@agr.nagoya-u.ac.jp) (luteinizing hormone [LH] and follicle-stimulating hormone [FSH]) from the anterior pituitary, regulating a seasonal development and regression of the gonads. In vertebrates, birds show drastic seasonal changes in gonad size, more than 100-fold, thereby contributing largely to our understanding of photoperiodic mechanisms. Among mammals, hamsters and sheep have often been used in studies of photoperiodism because of their drastic photoperiodic responses, although their seasonal gonadal changes are less dramatic than those of birds. The robust seasonal responses of birds may be related to their limited breeding season and the adaptations of birds to flight. In this review, we discuss the current understanding of the mechanisms regulating seasonal reproduction in birds and mammals and their relationship to the circadian clock.

\section{Regulation of Photoperiodism in Birds}

Among birds, the Japanese quail (Coturnix japonica) is a good model animal for understanding photoperiodism, because it shows a rapid response to changing day length [3]. Some studies have indicated that in quail, the mediobasal hypothalamus (MBH) is the center of seasonal reproduction for the following reasons: (1) lesions in the MBH suppressed photo-induced LH release [4, 5]; (2) local illumination in the brain induced testicular growth [6]; (3) electrical stimulation of the MBH led to LH secretion [7]; and (4) induction of c-Fos was observed under LD conditions [8]. Brief light pulses interrupting the long nights of SD conditions have also been demonstrated to induce a photoperiodic response [9]. The sensitive phase begins from 11 to $16 \mathrm{~h}$ after dawn, and therefore, we hypothesized that some molecular events must occur within the $\mathrm{MBH}$ in response to light stimuli. Using the $\mathrm{MBH}$ of a quail that 
received a light pulse and no light pulse in the photo-inducible phase, differential subtractive hybridization identified induction of the type 2 deiodinase gene (DIO2) [10] encoding the thyroid hormone (TH)-activating enzyme that converts the prohormone thyroxine $\left(\mathrm{T}_{4}\right.$ ) to bioactive $\mathrm{T}_{3}$ (Fig. 1) [11]. DIO2 expression is upregulated under LD conditions and downregulated under SD conditions in the tanycytes of the ependymal cells (ECs) lining the ventrolateral walls of the third ventricle within the MBH [10]. In contrast, it was later found that expression of $\mathrm{DIO} 3$ (TH-inactivating enzyme type 3 deiodinase), which converts $T_{4}$ and $T_{3}$ to inactive $T_{3}$ (reverse $T_{3}$ : $\left.\mathrm{rT}_{3}\right)$ and 3,3'-diiodothyronine $\left(\mathrm{T}_{2}\right)$, respectively, is upregulated under SD conditions and downregulated under LD conditions [12]. This switching may be responsible for the 10-fold higher concentration of $\mathrm{TH}$ in the MBH under LD conditions than under SD conditions, in spite of the constant level of plasma TH during both photoperiods. Intracerebroventricular (i.c.v.) $\mathrm{T}_{3}$ administration under $\mathrm{SD}$ conditions induced testicular growth in a dose-dependent manner, while the administration of a DIO2 inhibitor under LD conditions blocked testicular growth [10], indicating the functional significance of locally activated $\mathrm{TH}$.

It has been demonstrated that $\mathrm{TH}$ is important not only for the metabolism but also for the development and plasticity of the central nervous system [11]. In immunoelectron microscopy of the median eminence (ME) in quail kept under both SD and LD conditions, we found morphological changes between GnRH neurons and glial end feet [13] (Fig. 1). Under SD conditions, nerve terminals of the GnRH neurons were encased by the end feet of glial processes and did not contact the basal lamina, while under LD conditions, they seemed to be in close proximity to the basal lamina [13]. The administration of $\mathrm{T}_{3}$ into the brain under SD conditions mimicked LD-induced morphological changes [14]. Neuroendocrine terminals must be in direct contact with the pericapillary space (i.e., the basal lamina) in order to secrete the neurohormone into the hypophyseal portal vessel [15]. It is also noteworthy that seasonal plasticity within the GnRH system is reported in the ewe [16]. These reports appear to support the hypothesis that the $\mathrm{T}_{3}$-induced morphological changes between GnRH neurons and glial cells regulate seasonal GnRH secretion. In addition to the photoperiodic regulation of GnRH secretion by the morphological changes in the ME, seasonal changes in GnRH synthesis, mainly in the POA, are important for seasonal reproduction among birds such as starlings. However, because it has been reported that GnRH synthesis in quail is not seasonal [17], secretion of GnRH may be a more important event for seasonal reproduction than photo-induced GnRH synthesis in quail.

To clarify the mechanism involved in regulating the photoperiodic switching of $\mathrm{DIO} 2 / \mathrm{DIO} 3$ in the quail $\mathrm{MBH}$, we used a chicken highdensity oligonucleotide microarray (Affymetrix Chicken Genome Array) to perform genome-scale gene expression analysis during the transition from SD conditions to LD conditions in Japanese quail [18]. Analysis of more than 38,000 probes identified induction of thyroid-stimulating hormone $\beta$ subunit (TSHB) and the transcriptional co-activator eyes absent 3 (EYA3) in the pars tuberalis (PT) of the pituitary gland at $14 \mathrm{~h}$ after dawn on the first LD (Fig. 2). DIO2 was upregulated and DIO3 was suppressed $4 \mathrm{~h}$ later in the ECs. Since EYA3, a transcriptional co-activator, was expressed in adjacent but different regions of the ECs, EYA3 does not appear to be

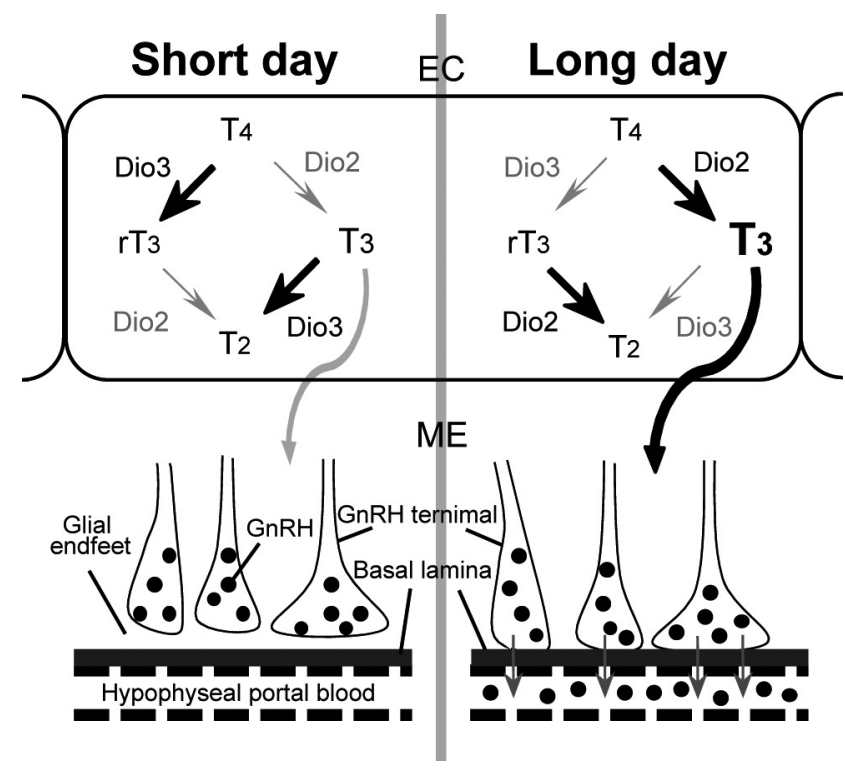

Fig. 1. DIO2 converts the prohormone thyroxine $\left(\mathrm{T}_{4}\right)$ to bioactive triiodothyronine $\left(\mathrm{T}_{3}\right)$ under $\mathrm{LD}$ conditions, while DIO3 metabolizes THs under SD conditions in birds and mammals. In quail, LD-induced $\mathrm{T}_{3}$ appears to induce morphological changes in the GnRH nerve terminals and glial processes, thereby causing $\mathrm{GnRH}$ secretion into the hypophyseal portal blood. GnRH, gonadotropin-releasing hormone; LD, long-day; SD, short-day.

involved in $\mathrm{DIO} / \mathrm{DIO} 3$ expression. Therefore, we predicted that PT-derived TSH (PT-TSH) may regulate the seasonal DIO2/DIO3 switching. We also found the expression of TSH receptor (TSHR) and binding of ${ }^{125} \mathrm{I}$-labeled TSH in the ECs. Administration of i.c.v. bovine TSH induced $\mathrm{DIO} 2$ expression and testicular growth under SD conditions, while passive immunization by administration of anti-TSH $\beta$ antibodies suppressed LD-induced DIO2 expression in the ECs. These data suggest that PT-TSH is a master regulator of seasonal reproduction in birds. Promoter analysis supported the involvement of the TSHR-Gs $\alpha$-cAMP signaling pathway in this TSH-DIO2 process.

\section{Regulation of Photoperiodism in Mammals}

Photoperiodic regulation of $\mathrm{DIO} 2$ and/or $\mathrm{DIO} 3$ has also been demonstrated in mammals, including the Siberian hamster [19, 20], Syrian hamster [21, 22], rat [23, 24], goat [25] and sheep [26], as well as birds (e.g., tree sparrow [27] and chicken [28]). Local activation of TH by $\mathrm{DIO} / \mathrm{DIO} 3$ switching within the $\mathrm{MBH}$ is also important for seasonal reproduction in both LD breeding birds and mammals, as daily subcutaneous (s.c.) $\mathrm{T}_{3}$ injection induced testicular growth [29] and chronic infusion of $\mathrm{T}_{3}$ into the brain prevented testicular regression [30] in Siberian hamsters. In sheep, $\mathrm{T}_{4}$ administration suppressed the breeding activity via a decrease in serum LH [31, 32] and LD stimulation activated the TSH-DIO2 pathway [26]. It has been known for several decades that thyroidectomy blocks the photoperiodic response in a number of species, such as the sparrow [33], starling [34], and sheep [35]. The involvement of TH in 
a
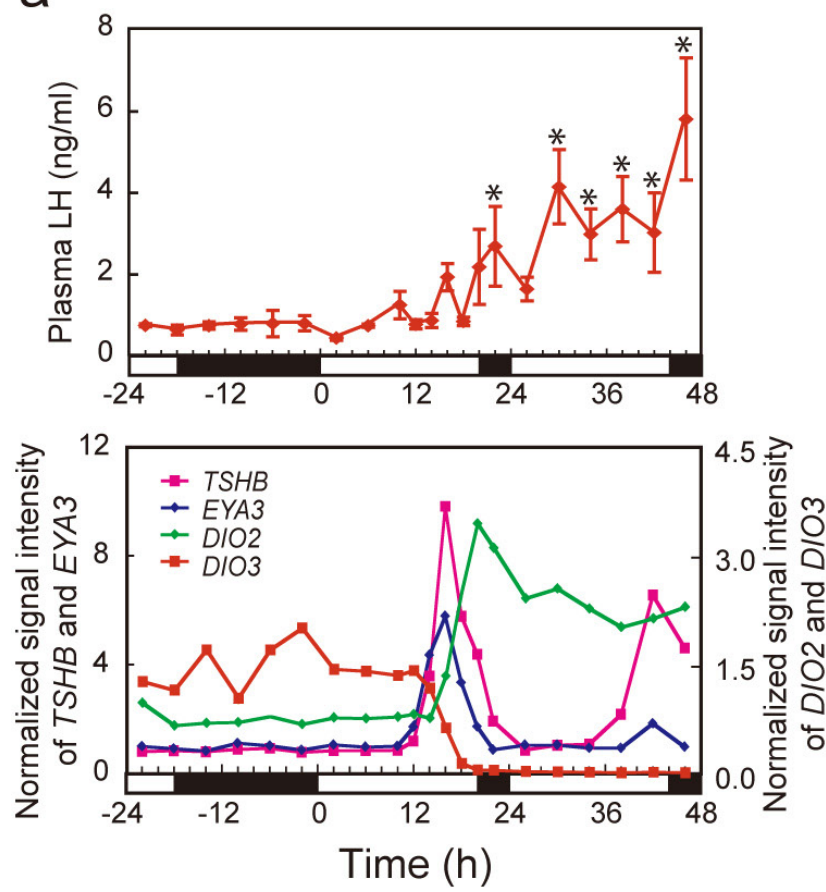

b

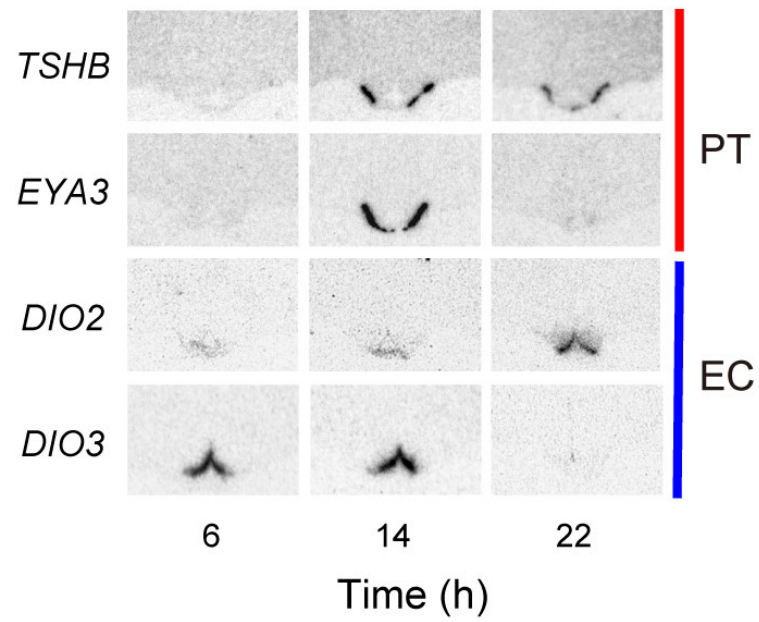

Fig. 2. Temporal expression profile of photoperiodic genes during the photo-induction process. (a) Long day-induced plasma LH concentration. Expression of first-wave genes (TSHB and EYA3) was induced within $14 \mathrm{~h}$ of the first LD after dawn, and expression of second-wave genes (DIO2 and DIO3) occurred $4 \mathrm{~h}$ later. (b) The first-wave genes were expressed in the pars tuberalis (PT), whereas the second-wave genes were expressed in the ependymal cells (ECs). The time $0 \mathrm{~h}$ corresponds to dawn on the first long day. Modified from previous data [18]. LH, luteinizing hormone.

photoperiodism has also been suggested [36].

Melatonin is a hormone synthesized and secreted from the pineal gland during the night. It is responsible for detecting the length of the night, and it also plays a critical role in seasonal reproduction in mammals. For example, pinealectomy blocks seasonal reproduction, whereas melatonin administration mimics the effect of short days on reproductive function [37-39]. The mechanism of melatonin action on seasonal reproduction has been gradually uncovered. Reppert et al. have cloned 2 melatonin receptors (MT1 and MT2) in mammals $[40,41]$. Since the MT1 receptor is reported to be expressed in the thyrotroph cells of the PT [42, 43], but not in the ECs [44, 45], melatonin appears to affect $\mathrm{DIO} / \mathrm{DIO} 3$ switching via TSH in the PT. Although laboratory mice are insensitive to photoperiod, transgenic and gene-targeted mice are excellent models for understanding the molecular mechanisms underlying photoperiodic response. Arylalkylamine $N$-acetyltransferase (AA-NAT) and hydroxyindole$O$-methyltransferase (HIOMT) [46] are rate-limiting enzymes in melatonin synthesis in the pineal gland. However, because most laboratory mice do not express these enzymes and cannot produce melatonin [47, 48], the photoperiodic response in melatonin-proficient strains and melatonin-deficient strains was analyzed. TSHB, DIO2, and DIO3 expression changed photoperiodically in the melatoninproficient CBA strain, whereas no response was observed in the melatonin-deficient C57BL strains [24]. Daily intraperitoneal (i.p.) administration of melatonin into C57BL mice induced an SD-like effect in these photoperiodic genes [24]. From these results, we concluded that mice are an excellent model for the study of molecular mechanisms of photoperiodic response at the gene level. Our group also found that TSHR-knockout mice did not respond to melatonin administration, suggesting that TSHR mediates melatonin regulation of the TSH-DIO2 signaling pathway. Examination of the effect of photoperiod and melatonin on mice lacking the MT1 or MT2 receptors identified the MT1 melatonin receptor as the mediator of melatonin effects on photoperiodic signal transduction [49]. Because LD-induction of TSHB in the PT has been also reported in SD breeder sheep [26], PT-TSH appears to mediate photoperiodic information in both LD and SD breeders, indicating the different mechanism of $\mathrm{T}_{3}$ action between LD breeders and SD breeders.

\section{Involvement of the Circadian Clock in Photoperiodism}

In Japanese quail, it has been reported that testicular growth can be observed during the transition from SD conditions to photoperiods longer than $11.5 \mathrm{~h}$ [50]. In hamsters, day length greater than 12.5 $\mathrm{h}$ induces testicular growth $[51,52]$. These photoperiods are called the "critical photoperiod" to induce the photoperiodic response. It is also known that light pulses during a limited time at night during SD conditions induce a photoperiodic response; this limited time is called the "photo-inducible phase" [8]. In resonance experiments in which house finch and quail were exposed to a day-length duration 


\section{Mammals}

Birds

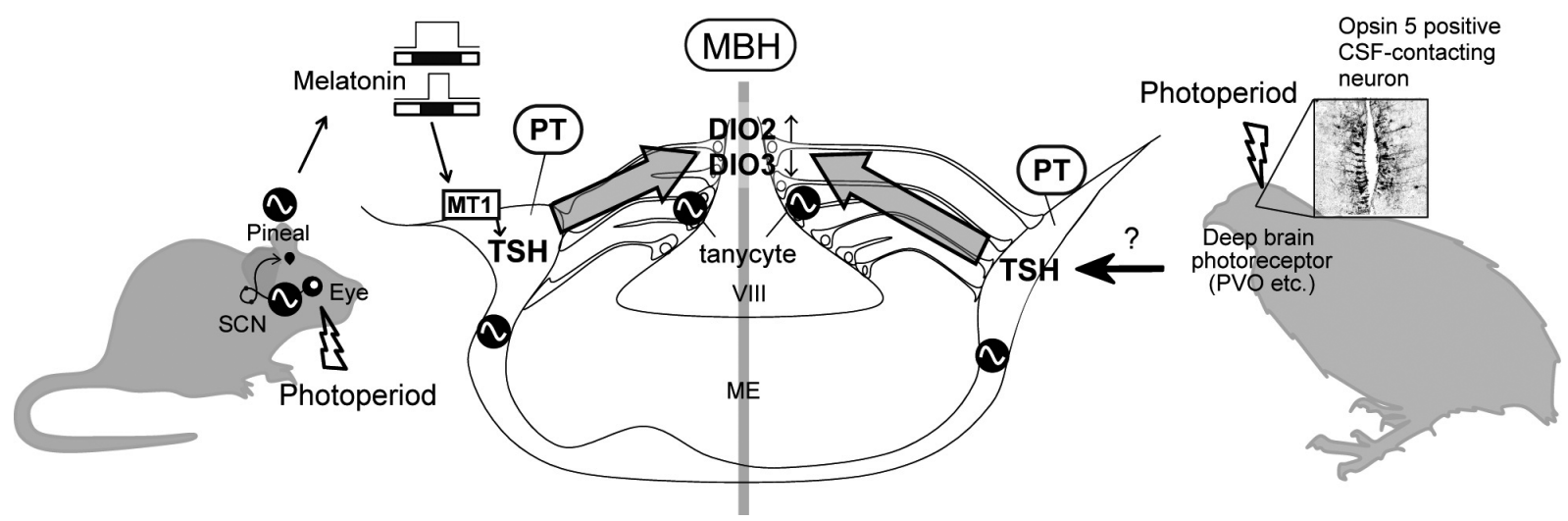

Fig. 3. Mechanism of photoperiodic signal transduction in mammals and birds. Melatonin mediates the transmission of photoperiodic information received by the eyes in mammals, while deep brain photoreceptor(s) (e.g., Opsin 5) directly receive light through the scalp in birds. LD-induced pars tuberalis (PT)-derived TSH acts on the tanycyte of the ependymal cells (ECs) to induce DIO2 expression and reduce $\mathrm{DIO} 3$ expression in both mammals and birds. TSH, thyroid-stimulating hormone.

of $6 \mathrm{~h}$ and varying duration of night length in multiples of $12 \mathrm{~h}$ (e.g., $6 \mathrm{~h}$ light [L], 18 h dark [D] cycle; 6 L 18 D, 6 L 30 D, 6 L 42 D, $6 \mathrm{~L} 54 \mathrm{D})$, light stimulus during the photo-inducible phase with a circadian-based rhythm induced testicular development [8,53]; in even multiples of $12 \mathrm{~h}$ (e.g., 6 L 18 D, 6 L 42 D), every other light pulse induced a photoperiodic response, while in odd multiples of $12 \mathrm{~h}$ (e.g., 6 L 30 D, 6 L 54 D), the photoperiodic response was not observed because of light exposure in the insensitive phase of the rhythm of photosensitivity. Similar observations were also reported in golden hamsters [54]. These results suggest that $6 \mathrm{~h}$ of light pulse during the photo-inducible phase of the day in light cycles that are multiples of $24 \mathrm{~h}$ induces the photoperiodic response, indicating the involvement of the circadian clock in photoperiodic time measurement. Involvement of the circadian clock in the regulation of photoperiodism in fish [55] and reptiles [56] has also been reported.

\section{Light Input Pathway for Seasonal Reproduction in Birds and Mammals}

The only known photoreceptor in mammals is the eye, and removal of the eyes blocks the photoperiodic response [39]. The master circadian pacemaker is localized in the suprachiasmatic nucleus (SCN) in mammals [57, 58]. Photoperiodic, or light, information received by the eyes is transmitted to the pineal gland via the SCN $[39,46]$ (Fig. 3). In the pineal gland, melatonin is synthesized and secreted during the night and acts as the night-length signal as described above. Melatonin is secreted into the cerebrospinal fluid (CSF) in the third ventricle through the pineal recess, an evagination of the third ventricle [59]. However, it remains unclear whether melatonin secreted into blood or into the third ventricle CSF is more effective during seasonal reproduction. Because the $\mathrm{SCN}$ is required to generate nocturnal melatonin secretion profiles, $\mathrm{SCN}$ lesions also disrupt the photoperiodic response in hamsters. Hamsters with SCN lesions do not show gonadal regression regardless of short photoperiods $[60,61]$.
Functional photoreceptors in birds appear to be localized in the eye, the pineal organ and the deep brain. The master circadian pacemakers are localized not only in the SCN but also in the eyes and the pineal organ [62-65]. In contrast to mammals, disruption of these regions (removal of the eyes in ducks [66], lesions around the SCN [5] or pinealectomy [67] in quail) does not affect the photoperiodic response. In addition, the effect of melatonin on seasonal reproduction in birds differs from that in mammals. Melatonin has little effect on the photoperiodic response in avian gonads regardless of nocturnal secretion of melatonin in birds as well as in mammals [68, 69]. These findings suggest that the mechanism of seasonal reproduction differs between birds and mammals.

In birds, photoreceptors in the deep brain are involved in the reception of photoperiodic information. The injection of India ink under the scalp blocks testicular recrudescence [70], and light stimulation by implantation of an illuminant in the MBH or septal region of the telencephalon induces gonadal growth $[6,66]$. Recent studies have shown the expression of several rhodopsin superfamily genes (melanopsin, VA opsin, and Opsin 5) in the avian brain [71-74]. Among these, Opsin 5, which is called neuropsin, is expressed in the CSF-contacting neurons within the paraventricular organ (PVO) in the hypothalamus and appears to respond to short-wavelength light (from UV to blue light), while melanopsin and/or VA opsin responds to longer-wavelength light $(480 \mathrm{~nm})$ than Opsin 5. Because Opsin 5-positive neurons project to the external layer of the ME adjacent to the PT in quail, it was predicted that light information received by the Opsin 5-expressing CSF-contacting neurons is transmitted to the PT, where it leads to partial or complete induction of TSH in the PT [73] (Fig. 3). However, the effects of Opsin 5 and other photoreceptors such as melanopsin and VA-opsin on the photoperiodic response in birds remain unclear. 


\section{Circadian Clock and Photoperiodic Time Measurement}

It is well established that the transcription-translation feedback loop of circadian clock genes generate circadian rhythm $[75,76]$, although the existence of a circadian clock mechanism that lacks a transcription-translation feedback loop was recently suggested in some studies [77-79]. Clock genes are also expressed not only in the pacemaker(s) but also in other regions of the brain and in peripheral tissues [80-82], leading to alterations in physiology and behavior [83]. In birds, because the circadian pacemakers are not essential for the photoperiodic response, the existence of another "photoperiodic clock" has been suggested. Rhythmic expression of clock genes and proteins was observed in the $\mathrm{MBH}$ as well as in the master pacemakers $[84,85]$. Although the photoperiod affects the temporal expression profiles of clock genes in the SCN and the pineal gland, in the $\mathrm{MBH}$, these genes are stable under various photoperiodic schedules, and perhaps contribute to the stable photo-inducible phase in animals [84].

In mammals and birds, temporal expression patterns of circadian clock genes in the SCN change under different photoperiods [86-91]. It has been suggested that the photoperiod is encoded at the neuronal network level in the SCN $[92,93]$, and clock genes in the SCN detect seasonal time [89, 90, 94-96]. The "internal coincidence model" for photoperiodic time measurement, which predicts the existence of 2 internal oscillators with alteration of their phase relationship, has also been proposed [97]. Lincoln et al. suggested that this internal coincidence timer in the PT provides a potential mechanism for generating the photoperiodic response, because rhythmic expression of circadian clock genes was observed in the ovine PT and the phase relationship between the morning Period (Per) peaks and the evening Cryptochrome (Cry) peak changed among photoperiods [98, 99]. The expressions of clock genes in the PT are influenced by changing photoperiods in both birds and mammals $[88,91,98,100-102]$. However, the involvement of the circadian clock genes and the internal coincidence timer within the PT in the photoperiodic responses of $T S H B, D I O 2$ and $D I O 3$ remains unknown. The circadian clock gene Per 2 is one of the most important clock genes [103-108] and is a component of the internal coincidence timer [98]. To examine whether Per2 is involved in photoperiodic response, we generated melatonin-proficient Per2-deletion mutant mice by using the speed congenic method. Although the amplitude of clock gene (Per1, Cryl) expression was greatly attenuated in the SCN and the PT of Per2 mutant mice, the expression profile of Aanat was unaffected in the pineal gland, and robust photoperiodic responses of the TSHB, DIO2 and $\mathrm{DIO} 3$ genes were observed. These results indicate that Per 2 is not necessary for photoperiodic responses in mice and that the internal coincidence timer in the PT is not a universal mechanism. Recently, it was also reported that LD-induced EYA3 appears to regulate TSHB expression in the PT through the circadian transcription factor thyrotropin embryonic factor (TEF) in mammals $[109,110]$. Phase synchronization and direct suppression of $E Y A 3$ expression by melatonin may be linked with the induction of $E Y A 3$ expression in the morning under LD conditions to induce $T S H B$ expression. This "external coincidence" timer [111] indicates the possible involvement of the circadian clock in the photoperiodic response in mammals.

\section{Conclusion}

Recent studies have uncovered that the PT is the most important regulatory relay point from photoreception to photoperiodic physiological changes in birds and mammals. In addition to birds and mammals, an anatomically distinct PT has been observed in reptiles and amphibians, but not in fish. Therefore, identification of the photoperiodic center in fish is expected in the future.

It is well established that the circadian clock is involved in the photoperiodic response in various vertebrates, including fish [55], reptiles [56], birds [8, 53] and mammals [54]. Recently, molecular mechanisms for the generation of circadian rhythms and photoperiodic signal transduction have gradually been understood. However, the mechanism of measurement of day length by the circadian clock (i.e., definition of the photo-inducible phase or critical photoperiod) remains unclear.

\section{References}

1. Garner WW, Allard HA. Effect of the relative length of day and night and other factors of the environment on growth and reproduction in plants. J Agric Res 1920; 18: 553-606.

2. Rowan W. Relation of light to bird migration and developmental changes. Nature 1925; 115: 494-495

3. Follett BK, King VM, Meddle SL. Rhythms and photoperiodism in birds. In: Lumsden PJ, Miller AJ (eds.), Biological Rhythms and Photoperiodism in Plants. Oxford: Biostatistics Scientific; 1998: 231-242

4. Sharp PJ, Follett BK. The effect of hypothalamic lesions on gonadotrophin release in Japanese quail (Coturnix coturnix japonica). Neuroendocrinology 1969; 5: 205-218. [Medline]

5. Davies DT, Follett BK. The neuroendocrine control of gonadotrophin release in the Japanese quail. II. The role of the anterior hypothalamus. Proc R Soc Lond B 1975; 191: 303-315. [Medline]

6. Homma K, Ohta M, Sakakibara Y. In: Suda M, Hayaishi O, Nakagawa H (eds.), Biological Rhythms and Their Central Mechanism. Amsterdam: Elsevier; 1979: 85-94.

7. Konishi H, Foster RG, Follett BK. Evidence for a daily rhythmicity in the acute release of LH in response to electrical stimulation in the Japanese quail. J Comp Physiol A Sens Neural Behav Physiol 1987; 161: 315-319.

8. Meddle SL, Follett BK. Photoperiodically driven changes in Fos expression within the basal tuberal hypothalamus and median eminence of Japanese quail. J Neurosci 1997; 17: 8909-8918. [Medline]

9. Follett BK, Sharp PJ. Circadian rhythmicity in photoperiodically induced gonadotrophin release and gonadal growth in the quail. Nature 1969; 223: 968-971. [Medline]

10. Yoshimura T, Yasuo S, Watanabe M, Iigo M, Yamamura T, Hirunagi K, Ebihara S. Light-induced hormone conversion of $\mathrm{T}_{4}$ to $\mathrm{T}_{3}$ regulates photoperiodic response of gonads in birds. Nature 2003; 426: 178-181. [Medline]

11. Bernal J. Action of thyroid hormone in brain. J Endocrinol Invest 2002; 25: 268-288 [Medline]

12. Yasuo S, Watanabe M, Nakao N, Takagi T, Follett BK, Ebihara S, Yoshimura T. The reciprocal switching of two thyroid hormone-activating and -inactivating enzyme genes is involved in the photoperiodic gonadal response of Japanese quail. Endocrinology 2005; 146: 2551-2554. [Medline]

13. Yamamura T, Hirunagi K, Ebihara S, Yoshimura T. Seasonal morphological changes in the neuro-glial interaction between gonadotropin-releasing hormone nerve terminals and glial endfeet in Japanese quail. Endocrinology 2004; 145: 4264-4267. [Medline]

14. Yamamura T, Yasuo S, Hirunagi K, Ebihara S, Yoshimura T. $T_{3}$ implantation mimics photoperiodically reduced encasement of nerve terminals by glial processes in the median eminence of Japanese quail. Cell Tissue Res 2006; 324: 175-179. [Medline]

15. Prevot V, Croix D, Bouret S, Dutoit S, Tramu G, Stefano GB, Beauvillain JC. Definitive evidence for the existence of morphological plasticity in the external zone of the median eminence during the rat estrous cycle: implication of neuro-glio-endothelial interactions in gonadotropin-releasing hormone release. Neuroscience 1999; 94: 809-819. [Medline]

16. Jansen HT, Cutter C, Hard S, Lehman MN, Goodman RL. Seasonal plasticity within 
the gonadotropin-releasing hormone $(\mathrm{GnRH})$ system of the ewe: Changes in identified GnRH inputs and glial association. Endocrinology 2003; 144: 3663-3676. [Medline]

17. Foster RG, Panzica GC, Parry DM, Viglietti-Panzica C. Immunocytochemical studies on the LHRH system of the Japanese quail: influence by photoperiod and aspects of sexual differentiation. Cell Tissue Res 1988; 253: 327-335. [Medline]

18. Nakao N, Ono H, Yamamura T, Anraku T, Takagi T, Higashi K, Yasuo S, Katou Y, Kageyama S, Uno Y, Kasukawa T, Iigo M, Sharp PJ, Iwasawa A, Suzuki Y, Sugano S, Niimi T, Mizutani M, Namikawa T, Ebihara S, Ueda HR, Yoshimura T. Thyrotrophin in the pars tuberalis triggers photoperiodic response. Nature 2008; 452: 317-322. [Medline]

19. Watanabe M, Yasuo S, Watanabe T, Yamamura T, Nakao N, Ebihara S, Yoshimura T. Photoperiodic regulation of type 2 deiodinase gene in Djungarian hamster: possible homologies between avian and mammalian photoperiodic regulation of reproduction. Endocrinology 2004; 145: 1546-1549. [Medline]

20. Herwig A, Wilson D, Logie TJ, Boelen A, Morgan PJ, Mercer JG, Barrett P. Photoperiod and acute energy deficits interact on components of the thyroid hormone system in hypothalamic tanycytes of the Siberian hamster. Am J Physiol Regul Integr Comp Physiol 2009; 296: R1307-R1315. [Medline]

21. Revel FG, Saboureau M, Pevet P, Mikkelsen JD, Simonneaux V. Melatonin regulates type 2 deiodinase gene expression in the Syrian hamster. Endocrinology 2006; 147: 4680-4687. [Medline]

22. Yasuo S, Yoshimura T, Ebihara S, Korf HW. Temporal dynamics of type 2 deiodinase expression after melatonin injections in Syrian hamsters. Endocrinology 2007a; 148: 4385-4392. [Medline]

23. Yasuo S, Watanabe M, Iigo M, Nakamura TJ, Watanabe T, Takagi T, Ono H, Ebihara S, Yoshimura T. Differential response of type 2 deiodinase gene expression to photoperiod between photoperiodic Fischer 344 and nonphotoperiodic Wistar rats. Am J Physiol Regul Integr Comp Physiol 2007b; 292: R1315-R1319. [Medline]

24. Ono H, Hoshino Y, Yasuo S, Watanabe M, Nakane Y, Murai A, Ebihara S, Korf HW, Yoshimura T. Involvement of thyrotropin in photoperiodic signal transduction in mice. Proc Natl Acad Sci USA 2008; 105: 18238-18242. [Medline]

25. Yasuo S, Nakao N, Ohkura S, Iigo M, Hagiwara S, Goto A, Ando H, Yamamura T, Watanabe M, Watanabe T, Oda S, Maeda K, Lincoln GA, Okamura H, Ebihara S, Yoshimura T. Long-day suppressed expression of type 2 deiodinase gene in the mediobasal hypothalamus of the Saanen goat, a short-day breeder: implication for seasonal window of thyroid hormone action on reproductive neuroendocrine axis. Endocrinology 2006; 147: 432-440. [Medline]

26. Hanon EA, Lincoln GA, Fustin JM, Dardente H, Masson-Pévet M, Morgan PJ, Hazlerigg DG. Ancestral TSH mechanism signals summer in a photoperiodic mammal. Curr Biol 2008; 18: 1147-1152. [Medline]

27. Watanabe T, Yamamura T, Watanabe M, Yasuo S, Nakao N, Dawson A, Ebihara S, Yoshimura T. Hypothalamic expression of thyroid hormone-activating and -inactivating enzyme genes in relation to photorefractoriness in birds and mammals. Am J Physiol Regul Integr Comp Physiol 2007; 292: R568-R572. [Medline]

28. Ono H, Nakao N, Yamamura T, Kinoshita K, Mizutani M, Namikawa T, Iigo M, Ebihara S, Yoshimura T. Red jungle fowl (Gallus gallus) as a model for studying the molecular mechanism of seasonal reproduction. Anim Sci J 2009; 80: 328-332. [Medline]

29. Freeman DA, Teubner BJ, Smith CD, Prendergast BJ. Exogenous $\mathrm{T}_{3}$ mimics long day lengths in Siberian hamsters. Am J Physiol Regul Integr Comp Physiol 2007; 292: R2368-R2372. [Medline]

30. Barrett P, Ebling FJ, Schuhler S, Wilson D, Ross AW, Warner A, Jethwa P, Boelen A, Visser TJ, Ozanne DM, Archer ZA, Mercer JG, Morgan PJ. Hypothalamic thyroid hormone catabolism acts as a gatekeeper for the seasonal control of body weight and reproduction. Endocrinology 2007; 148: 3608-3617. [Medline]

31. Billings HJ, Viguié C, Karsch FJ, Goodman RL, Connors JM, Anderson GM. Temporal requirements of thyroid hormones for seasonal changes in luteinizing hormone secretion. Endocrinology 2002; 143: 2618-2625. [Medline]

32. Anderson GM, Hardy SL, Valent M, Billings HJ, Connors JM, Goodman RL. Evidence that thyroid hormones act in the ventromedial preoptic area and the premammillary region of the brain to allow the termination of the breeding season in the ewe. Endocrinology 2003; 144: 2892-2901. [Medline]

33. Dawson A. Thyroidectomy of house sparrows (Passer domesticus) prevents photoinduced testicular growth but not the increased hypothalamic gonadotrophin-releasing hormone. Gen Comp Endocrinol 1998; 110: 196-200. [Medline]

34. Dawson A. Thyroidectomy progressively renders the reproductive system of starlings (Sturnus vulgaris) unresponsive to changes in daylength. J Endocrinol 1993; 139: 51-55. [Medline]

35. Nicholls TJ, Follett BK, Goldsmith AR, Pearson H. Possible homologies between photorefractoriness in sheep and birds: the effect of thyroidectomy on the length of the ewe's breeding season. Reprod Nutr Dev 1988; 28: 375-385. [Medline]

36. Follett BK, Nicholls TJ. Influences of thyroidectomy and thyroxine replacement on photoperiodically controlled reproduction in quail. J Endocrinol 1985; 107: 211-221.
[Medline]

37. Carter DS, Goldman BD. Progonadal role of the pineal in the Djungarian hamster (Phodopus sungorus sungorus): mediation by melatonin. Endocrinology 1983; 113 1268-1273. [Medline]

38. Hoffman RA, Reiter RJ. Pineal gland: influence on gonads of male hamsters. Science 1965; 148: 1609-1611. [Medline]

39. Reiter RJ. The pineal and its hormones in the control of reproduction in mammals. Endocr Rev 1980; 1: 109-131. [Medline]

40. Reppert SM, Weaver DR, Ebisawa T. Cloning and characterization of a mammalian melatonin receptor that mediates reproductive and circadian responses. Neuron 1994; 13: 1177-1185. [Medline]

41. Reppert SM, Godson CG, Mahle CD, Weaver DR, Slaugenhaupt SA, Gusella JF. Molecular characterization of a second melatonin receptor expressed in human retina and brain: the Mel1b-melatonin receptor. Proc Natl Acad Sci USA 1995; 92: 8734-8738. [Medline]

42. Klosen P, Bienvenu C, Demarteau O, Dardente H, Guerrero H, Pévet P, MassonPévet M. The mtl Melatonin receptor and RORb receptor are co-localized in specific TSH-immunoreactive cells in the pars tuberalis of the rat pituitary. J Histochem Cytochem 2002; 50: 1647-1657. [Medline]

43. Wittkowski W, Bergmann M, Hoffmann K, Pera F. Photoperiod-dependent changes in TSH-like immunoreactivity of cells in the hypophysial pars tuberalis of the Djungarian hamster, Phodopus sungorus. Cell Tissue Res 1988; 251: 183-187. [Medline]

44. Schuster C, Gauer F, Guerrero H, Lakhdar-Ghazal N, Pévet P, Masson-Pévet M. Photic regulation of $\mathrm{mt} 1$ melatonin receptors in the Siberian hamster pars tuberalis and suprachiasmatic nuclei: involvement of the circadian clock and intergeniculate leaflet. $J$ Neuroendocrinol 2000; 12: 207-216. [Medline]

45. Song CK, Bartness TJ. CNS sympathetic outflow neurons to white fat that express MEL receptors may mediate seasonal adiposity. Am J Physiol Regul Integr Comp Physiol 2001; 281: R666-R672. [Medline]

46. Arendt J. Melatonin and the Mammalian Pineal Gland. London: Chapman \& Hall; 1995.

47. Ebihara S, Marks T, Hudson DJ, Menaker M. Genetic control of melatonin synthesis in the pineal gland of the mouse. Science 1986; 231: 491-493. [Medline]

48. Goto M, Oshima I, Tomita T, Ebihara S. Melatonin content of the pineal gland in different mouse strains. J Pineal Res 1989; 7: 195-204. [Medline]

49. Yasuo S, Yoshimura T, Ebihara S, Kolf HW. Melatonin transmits photoperiodic signals through the MT1 melatonin receptor. J Neurosci 2009; 29: 2885-2889. [Medline]

50. Follett BK, Maung SL. Rate of testicular maturation, in relation to gonadotrophin and testosterone levels, in quail exposed to various artificial photoperiods and to natural daylengths. J Endocrinol 1978; 78: 267-280. [Medline]

51. Elliott JA. Circadian rhythms and photoperiodic time measurement in mammals. Fed Proc 1976; 35: 2339-2346. [Medline]

52. Goldman BD. Mammalian photoperiodic system: formal properties and neuroendocrine mechanisms of photoperiodic time measurement. J Biol Rhythms 2001; 16: 283-301. [Medline]

53. Hamner WM. Diurnal rhythm and photoperiodism in testicular recrudescence of the house finch. Science 1963; 142: 1294-1295. [Medline]

54. Elliott JA, Stetson MH, Menaker M. Regulation of testis function in golden hamsters: A circadian clock measures photoperiodic time. Science 1972; 178: 771-773. [Medline]

55. Baggerman B. Photoperiodic responses in the stickleback and their control by a daily rhythm of photosensitivity. Gen Comp Endocrinol Suppl 1972; 3: 466-476.

56. Underwood H, Hyde LL. A circadian clock measures photoperiodic time in the male lizard Anolis carolinensis. J Comp Physiol A 1990; 167: 231-243.

57. Inouye ST, Kawamura H. Persistence of circadian rhythmicity in a mammalian hypothalamic "island" containing the suprachiasmatic nucleus. Proc Natl Acad Sci USA 1979; 76 5962-5966. [Medline]

58. Ralph MR, Foster RG, Davis FC, Menaker M. Transplanted suprachiasmatic neucleus determines circadian period. Science 1990; 247: 975-978. [Medline]

59. Tricoire H, Locatelli A, Chemineau P, Malpaux B. Melatonin enters the cerebrospinal fluid through the pineal recess. Endocrinology 2002; 143: 84-90. [Medline]

60. Rusak B, Morin LP. Testicular responses to photoperiod are blocked by lesions of the suprachiasmatic nuclei in golden hamsters. Biol Reprod 1976; 15: 366-374. [Medline]

61. Stetson MH, Watson-Whitmyre M. Nucleus suprachiasmaticus: The biological clock of the hamster? Science 1976; 191: 197-199. [Medline]

62. Ebihara S, Kawamura H. The role of the pineal organ and the suprachiasmatic nucleus in the control of circadian locomotor rhythms in the Java sparrow, Padda oryzivora. J Comp Physiol A 1981; 141: 207-214.

63. Takahashi JS, Menaker M. Role of the suprachiasmatic nucleus in the circadian system of the house sparrow. J Neurosci 1982; 2: 815-828. [Medline]

64. Yoshimura T, Yasuo S, Suzuki Y, Makino E, Yokota Y, Ebihara S. Identification of the suprachiasmatic nucleus in birds. Am J Physiol Regul Integr Comp Physiol 2001; 280 R1185-R1189. [Medline]

65. Steele CT, Zivkovic BD, Siopes T, Underwood H. Ocular clocks are tightly coupled and 
act as pacemakers in the circadian system of Japanese quail. Am J Physiol Regul Integr Comp Physiol 2003; 284: R208-R218. [Medline]

66. Benoit J. Le role des yeux dans l'action stimulante de la lumiere sure le developpement testiulaire chez le canard. C R Soc Biol (Paris) 1935; 118: 669-671.

67. Siopes TD, Wilson WO. Extraocular modification of photoreception in intact and pinealectomized coturnix. Poult Sci 1974; 53: 2035-2041. [Medline]

68. Juss TS, Meddle SL, Servant RS, King VM. Melatonin and photoperiodic time measurement in Japanese quail (Coturnix coturnix japonica). Proc Biol Sci 1993; 254: 21-28. [Medline]

69. Gwinner E, Hau H, Heigl S. Melatonin: generaion and modification of avian circadian rhythms. Brain Res Bull 1997; 44: 439-444. [Medline]

70. Menaker M, Roberts R, Elliott J, Underwood H. Extraretinal light perception in the sparrow. III. The eyes do not participate in photoperiodic photoreception. Proc Natl Acad Sci USA 1970; 67: 320-325. [Medline]

71. Chaurasia SS, Rollag MD, Jiang G, Hayes WP, Haque R, Natesan A, Zatz M, Tosini G, Liu C, Korf HW, Iuvone PM, Provencio I. Molecular cloning, localization and circadian expression of chicken melanopsin (Opn4): differential regulation of expression in pineal and retinal cell types. J Neurochem 2005; 92: 158-170. [Medline]

72. Halford S, Pires SS, Turton M, Zheng L, Gonzalez-Menendez I, Davies WL, Peirson SN, Garcia-Fernandez JM, Hankins MW, Foster RG. VA opsin-based photoreceptors in the hypothalamus of birds. Curr Biol 2009; 19: 1396-1402. [Medline]

73. Nakane Y, Ikegami K, Ono H, Yamamoto N, Yoshida S, Hirunagi K, Ebihara S, Kubo Y, Yoshimura T. A mammalian neural tissue opsin (Opsin 5) is a deep brain photoreceptor in birds. Proc Natl Acad Sci USA 2010; 107: 15264-15268. [Medline]

74. Yamashita T, Ohuchi H, Tomonari S, Ikeda K, Sakai K, Shichida Y. Opn5 is a UVsensitive bistable pigment that couples with Gi subtype of G protein. Proc Natl Acad Sci USA 2010; 107: 22084-22089. [Medline]

75. Young MW, Kay SA. Time zones: a comparative genetics of circadian clocks. Nat Rev Genet 2001; 2: 702-715. [Medline]

76. Reppert SM, Weaver DR. Coordination of circadian timing in mammals. Nature 2002; 418: 935-941. [Medline]

77. Tomita J, Nakajima M, Kondo T, Iwasaki H. No transcription-translation feedback in circadian rhythm of KaiC phosphorylation. Science 2005; 307: 251-254. [Medline]

78. O'Neill JS, van Ooijen G, Dixon LE, Troein C, Corellou F, Bouget FY, Reddy AB, Miller AJ. Circadian rhythms persist without transcription in eukaryote. Nature 2011; 469: 554-558. [Medline]

79. O'Neill JS, Reddy AB. Circadian clocks in human red blood cells. Nature 2011; 469: 498-503. [Medline]

80. Yamazaki S, Numano R, Abe M, Hida A, Takahashi R, Ueda M, Block GD, Sakaki Y, Menaker M, Tei H. Resetting central and peripheral circadian oscillators in transgenic rats. Science 2000; 288: 682-685. [Medline]

81. Abe M, Herzog ED, Yamazaki S, Straume M, Tei H, Sakaki Y, Menaker M, Block GD. Circadian rhythms in isolated brain regions. J Neurosci 2002; 22: 350-356. [Medline]

82. Nagoshi E, Saini C, Bauer C, Laroche T, Naef F, Schibler U. Circadian gene expression in individual fibroblasts: cell-autonomous and self-sustained oscillators pass time to daughter cells. Cell 2004; 119: 693-705. [Medline]

83. Balsalobre A. Clock genes in mammalian peripheral tissues. Cell Tissue Res 2002; 309: 193-199. [Medline]

84. Yasuo S, Watanabe M, Okabayashi N, Ebihara S, Yoshimura T. Circadian clock genes and photoperiodism: Comprehensive analysis of clock gene expression in the mediobasal hypothalamus, the suprachiasmatic nucleus, and the pineal gland of Japanese quail under various light schedules. Endocrinology 2003; 144: 3742-3748. [Medline]

85. Ikegami K, Katou Y, Higashi K, Yoshimura T. Localization of circadian clock protein BMAL1 in the photoperiodic signal transduction machinery in Japanese quail. J Comp Neurol 2009; 517: 397-404. [Medline]

86. Sumová A, Jác M, Sládek M, Sauman I, Illnerová H. Clock gene daily profiles and their phase relationship in the rat suprachiasmatic nucleus are affected by photoperiod. $J$ Biol Rhythms 2003; 18: 134-144. [Medline]

87. Tournier BB, Menet JS, Dardente H, Poirel VJ, Malan A, Masson-Pe'vet M, Pe'vet P, Vuillez P. Photoperiod differentially regulates clock genes' expression in the suprachiasmatic nucleus of Syrian hamster. Neuroscience 2003; 118: 317-322. [Medline]

88. Johnston JD, Ebling FJ, Hazlerigg DG. Photoperiod regulates multiple gene expression in the suprachiasmatic nuclei and pars tuberalis of the Siberian hamster (Phodopus sungorus). Eur J Neurosci 2005; 21: 2967-2974. [Medline]

89. Inagaki N, Honma S, Ono D, Tanahashi Y, Honma K. Separate oscillating cell groups in mouse suprachiasmatic nucleus couple photoperiodically to the onset and end of daily activity. Proc Natl Acad Sci USA 2007; 104: 7664-7669. [Medline]
90. Naito E, Watanabe T, Tei H, Yoshimura T, Ebihara S. Reorganization of the suprachiasmatic nucleus coding for day length. J Biol Rhythms 2008; 23: 140-149. [Medline]

91. Ikegami K, Iigo M, Yoshimura T. Circadian clock gene Per2 is not necessary for the photoperiodic response in mice. PLoS ONE 2013; 8: e58482. [Medline]

92. VanderLeest HT, Houben T, Michel S, Deboer T, Albus H, Vansteensel MJ, Block GD, Meijer JH. Seasonal encoding by the circadian pacemaker of the SCN. Curr Biol 2007; 17: 468-473. [Medline]

93. Brown TM, Piggins HD. Spatiotemporal heterogeneity in the electrical activity of suprachiasmatic nuclei neurons and their response to photoperiod. J Biol Rhythms 2009; 24 44-54. [Medline]

94. Nuesslein-Hildesheim B, O'Brien JA, Ebling FJ, Maywood ES, Hastings MH. The circadian cycle of $m P E R$ clock gene products in the suprachiasmatic nucleus of the siberian hamster encodes both daily and seasonal time. Eur J Neurosci 2000; 12: 2856-2864 [Medline]

95. Hazlerigg DG, Ebling FJ, Johnston JD. Photoperiod differentially regulates gene expression rhythms in the rostral and caudal SCN. Curr Biol 2005; 15: R449-R450 [Medline]

96. Sosniyenko S, Hut RA, Daan S, Sumova A. Influence of photoperiod duration and light-dark transitions on entrainment of Per1 and Per2 gene and protein expression in subdivisions of the mouse SCN. Eur J Neurosci 2009; 30: 1802-1814. [Medline]

97. Pittendrigh CS. Circadian surfaces and the diversity of possible roles of circadian organization in photoperiodic induction. Proc Natl Acad Sci USA 1972; 69: 2734-2737. [Medline]

98. Lincoln G, Messager S, Andersson H, Hazlerigg DG. Temporal expression of seven clock genes in the suprachiasmatic nucleus and the pars tuberalis of the sheep: evidence for an internal coincidence timer. Proc Natl Acad Sci USA 2002; 99: 13890-13895. [Medline]

99. Lincoln GA, Andersson H, Loudon A. Clock genes in calendar cells as the basis of annual timekeeping in mammals - a unifying hypothesis. J Endocrinol 2003; 179: 1-13. [Medline]

100. Messager S, Ross AW, Barrett P, Morgan PJ. Decoding photoperiodic time through Per1 and ICER gene amplitude. Proc Natl Acad Sci USA 1999; 96: 9938-9943. [Medline]

101. Dardente H, Menet JS, Poirel VJ, Streicher D, Gauer F, Vivien-Roels B, Klosen P, Pe'vet P, Masson-Pe'vet M. Melatonin incuces Cryl expression in the pars tuberalis of the rat. Brain Res Mol Brain Res 2003; 114: 101-106. [Medline]

102. Yasuo S, Watanabe M, Tsukada A, Takagi T, Iigo M, Shimada K, Ebihara S, Yoshimura T. Photoinducible phase-specific light induction of $\mathrm{Cryl}$ gene in the pars tuberalis of Japanese quail. Endocrinology 2004; 145: 1612-1616. [Medline]

103. van der Horst GT, Muijtjens M, Kobayashi K, Takano R, Kanno S, Takao M, de Wit J, Verkerk A, Eker AP, van Leenen D, Buijs R, Bootsma D, Hoeijmakers JH, Yasui A. Mammalian $\mathrm{Cry} 1$ and $\mathrm{Cry} 2$ are essential for maintenance of circadian rhythms. Nature 1999; 398: 627-630. [Medline]

104. Zheng B, Albrecht U, Kaasik K, Sage M, Lu W, Vaishnav S, Li Q, Sun ZS, Eichele G, Bradley A, Lee CC. The $m P e r 2$ gene encodes a functional component of the mammalian circadian clock. Nature 1999; 400: 169-173. [Medline]

105. Bunger MK, Wilsbacher LD, Moran SM, Clendenin C, Radcliffe LA, Hogenesch JB, Simon MC, Takahashi JS, Bradfield CA. Mop3 is an essential component of the master circadian pacemaker in mammals. Cell 2000; 103: 1009-1017. [Medline]

106. Shearman LP, Jin X, Lee C, Reppert SM, Weaver DR. Targeted disruption of the mPer 3 gene: subtle effects on circadian clock function. Mol Cell Biol 2000; 20: 6269-6275. [Medline]

107. Zheng B, Albrecht U, Kaasik K, Sage M, Lu W, Sun ZS, Eichele G, Bradley A, Le CC. Nonredundant roles of the mPer 1 and $m P e r 2$ genes in the mammalian circadian clock. Cell 2001; 105: 683-694. [Medline]

108. Preitner N, Damiola F, Lopez-Molina L, Zakany J, Duboule D, Albrecht U, Schibler U. The orphan nuclear receptor REV-ERB $\alpha$ controls circadian transcription within the positive limb of the mammalian circadian oscillator. Cell 2002; 110: 251-260. [Medline]

109. Dardente H, Wyse C, Birnie M, Dupré S, Loudon A, Lincoln G, Hazlerigg D. A molecular switch for photoperiod responsiveness in mammals. Curr Biol 2010; 20: 2193-2198. [Medline]

110. Masumoto KH, Ukai-Tadenuma M, Kasukawa T, Nagano M, Uno KD, Tsujino K, Horikawa K, Shigeyoshi Y, Ueda HR. Acute induction of Eya3 by late-night light stimulation triggers TSHß expression in photoperiodism. Curr Biol 2010; 20: 2199-2206. [Medline]

111. Pittendrigh CS, Minis DH. The entrainment of circadian oscillations by light and their role as photoperiodic clocks. Am Nat 1964; 98: 261-294. 